\title{
Evaluation of the lymphoproliferation of mononuclear cells in cutaneous leishmaniasis patients treated with Libidibia ferrea
}

\author{
Erika Oliveira da Silva ${ }^{\bullet}$, Paula Figliuolo da Cruz Borges ${ }^{\mathrm{b}}$, Rafaela Benício Santana ${ }^{\mathrm{b}}{ }^{*}$, \\ Heriederson Sávio Dias Moura`®, José Fernando Marques Barcellosd®, Bruno Bezerra Jensenb®, \\ Francimeire Gomes Pinheirob®, Maricleide de Farias Naifføø, Thaís Tibery Espire®, \\ Antonia Maria Ramos Francobø \\ a Programa de Pós-Graduação em Imunologia Básica e Aplicada, Universidade Federal do Amazonas, Manaus,69080-900, \\ Amazonas, Brasil. *ericcaoliveira@hotmail.com \\ b Instituto Nacional de Pesquisas da Amazônia, Manaus, 69067-375, Amazonas, Brasil. \\ c Programa de Pós-Graduação Enfermagem em Saúde Pública, Universidade de São Paulo, Ribeirão Preto \\ 14040-902, São Paulo, Brasil. \\ d Universidade Federal do Amazonas, Manaus, 69054-298, Amazonas, Brasil. \\ e Universidade Federal do Amazonas, Manaus, 69067-005, Amazonas, Brasil.
}

Received: July 29, 2021 / Accepted: September 20, 2021 / Published online: September 30, 2021

\begin{abstract}
American integumentary leishmaniasis (ATL) is a neglected disease that mostly affects vulnerable populations. Its broad spectrum of clinical manifestations is related to the type of immune response produced by the host and the species of Leishmania involved. In recent years, the use of medicinal plants has become a therapeutic alternative in the treatment of infectious parasitic diseases. This research aimed to evaluate the lymphoproliferative responses of peripheral blood mononuclear cells (PBMCs) of patients with cutaneous leishmaniasis (CL) before and after treatment, and healthy individuals. The lymphoproliferative response was evaluated in cell culture using stimuli of the dichloromethane fraction (DCM) obtained from Libidibia ferrea, Glucantime ${ }^{\circledR}$ and phytohemagglutinin - PHA using a BrdU Cell Proliferation after $72 \mathrm{~h}$ of incubation. In cultures treated with the DCM fraction, intense induction of lymphoproliferation was observed ( $p<0.0001)$, as was also observed in response to the PHA mitogen, and there was a significant difference when compared with the conventional treatment $(\mathrm{p}<0.0135)$. In the posttreatment and healthy groups, although the compound induced lymphoproliferation, there was no statistical difference. These results suggest that the organic compound played an important inducing role in lymphoproliferation, which highlights the importance of continuity involving new studies in order to evaluate its immunomodulatory activity.
\end{abstract}

Keywords: Cell proliferation, leishmaniasis, natural products, therapeutic alternative.

\section{Avaliação da linfoproliferação de células mononucleares de pacientes com leishmaniose cutânea frente a Libidibia ferrea}

\begin{abstract}
Resumo
A leishmaniose tegumentar americana (LTA) é uma doença negligenciada que acomete majoritariamente populações vulneráveis. Seu amplo espectro de manifestações clínicas é relacionado ao tipo de resposta imunológica produzida pelo hospedeiro e a espécie de Leishmania envolvida. Nos últimos anos, o uso de plantas medicinais vem sendo uma alternativa terapêutica no tratamento de doenças infectoparasitárias. Esta pesquisa teve como objetivo avaliar as respostas linfoproliferativas de células mononucleares do sangue periférico (PBMCs) de pacientes com leishmaniose cutânea (LC) antes e após tratamento e de indivíduos sadios. A resposta linfoproliferativa foi avaliada em cultura de células frente a estímulos da fração diclorometânica (DCM) obtida de Libidibia ferrea, Glucantime ${ }^{\circledR}$ e phytohemagglutinin - PHA utilizando BrdU Cell Proliferation após $72 \mathrm{~h}$ de incubação. Nas culturas tratadas com a fração DCM foi observada em todos os grupos intensa indução da linfoproliferação $(p<0,0001)$, apresentando diferença significativa ao comparar com o tratamento convencional no grupo de pacientes pós-tratamento $(\mathrm{p}<0,0135)$. Estes resultados sugerem que o composto orgânico desempenhou importante ação indutora na linfoproliferação ressaltando a importância da continuidade com novos estudos a fim de avaliar sua atividade imunomodulatória.
\end{abstract}

Palavras-chave: Proliferação celular, leishmaniose, produtos naturais, alternativa terapêutica. 


\section{Introduction}

American tegumentary leishmaniasis (ATL) is classified by the World Health Organization (WHO) as a neglected tropical disease (NTD). In Brazil, it is considered a public health problem, whose case notification data from the Department of Informatics of the National Health System (SINAN, 2019) indicated 16,135 confirmed cases of ATL in 2019. The northern region had the highest incidence, with 7,123 cases of ATL in 2019, with 1,302 cases reported in the state of Amazonas. ATL is a disease caused by intracellular protozoa of the genus Leishmania (Kinetoplastida, Trypanosomatidae), with Leishmania (Leishmania) amazonensis, Leishmania (Vianna.) guyanensis and Leishmania (Vianna) braziliensis being the main species that cause ATL in Brazil (Brasil, 2017).

In the Amazon, ATL manifests itself in the cutaneous, diffuse cutaneous and mucosal forms, with cutaneous leishmaniasis (CL) being the most prevalent in the state of Amazonas (Brasil, 2017). CL is characterized by a diversity of clinical forms, the lesions of which can be localized or disseminated. The variability of clinical presentations depend on the species of Leishmania involved in the infection and the development of the patient's immune response (Brasil, 2017).

Regarding the mechanisms of immune regulation, there is a dichotomy between Th1 and Th2, since they induce important cytokine profiles that are capable of defining the clinical course of infection (Espir et al., 2014). In this context, the main human defense against leishmaniasis is its ability to adjust the cell-mediated immune response, which is demonstrated by lymphoproliferation and the production of high levels of IFN- $\gamma$ and TNF- $\alpha$, making it capable of controlling or even eliminating the parasite. Thus, lymphoproliferation is an important evaluation parameter, as it demonstrates the ability of a given cell or group of cells to proliferate in situations that may be adverse (Teixeira, Teixeira, Andrade, Barral-Netto, \& Barral, 2006; Bacellar et al., 2002).

For more than 50 years, the drugs recommended by the Brazilian Ministry of Health for treating leishmaniasis have been composed of pentavalent antimonials $\left(\mathrm{Sb}^{+5}\right)$ (Carvalho et al., 2019). Despite their effectiveness, $\mathrm{Sb}^{+5}$ presents a number of problems, such as parenteral administration, long duration of treatment, high toxicity and high cost. Thus, many patients who contract leishmaniasis abandon treatment, which is a factor that favors the appearance of resistant strains (Pradhan, Schwartz, Patil, Grabbe, \& Goldust, 2021).

Due to the high toxicity of the drugs that are currently used, new therapeutic alternatives have been studied, and Libidibia ferrea is one of the candidates. It is a plant that belongs to the Fabaceae family, and is popularly known in Brazil as "pauferro" or "jucá". L. ferrea has a multiplicity of therapeutic uses and its different plant parts are used in the treatment of various diseases. Therefore, given its medical importance, the Brazilian Ministry of Health has included this species in the National List of Important Medicinal Plants for the Health System and indicates that it has analgesic, antipyretic, antiinflammatory and/or antispasmodic (Brasil, 2006), and healing and antioxidant properties (Carvalho, Sampaio, Araújo, Pinto, \& Rocha, 2016; Falcão et al., 2019).
Antileishmanial activity was observed by ComandolliWyrepkowski et al. (2017), who confirmed that L. ferrea presented efficiency in the treatment of CL in in vitro and in vivo experiments. In this sense, considering the therapeutic relevance of $L$. ferrea, this study aimed to evaluate the action of a fraction obtained from the methanolic extract of $L$. ferrea on the lymphoproliferation of PBMC of people exposed to Leishmania sp. and compare it to those not exposed, for the purpose of providing subsidies for new Leishmaniasis treatment strategies.

\section{Materials and Methods}

\section{Plant material and fractionation}

Samples of the fruit of $L$. ferrea were collected in Manaus, Amazonas, Brazil ( $3^{\circ} 4^{\prime} 34^{\prime \prime}$ S 60 0'11' W). These were deposited in the Herbarium of the National Institute for Amazonian Research - INPA and identified under the number 246150. The collected fruits were sorted and, after removing the seeds, were dried, pulverized and extracted with the solvents hexane and methanol (ComandolliWyrepkowski et al., 2017). The dichloromethane fraction (DCM) of the L. ferrea extract was obtained by liquid-liquid partition. An aliquot of $20 \mathrm{~g}$ of methanolic extract solubilized in $200 \mathrm{~mL}$ of $\mathrm{H}_{2} \mathrm{O}: \mathrm{MeOH}(9: 1)$ was used and extracted three times with each of the solvents used in the partition (hexane and dichloromethane). After this process, the fraction was concentrated in a rotary evaporator (YAMATO ${ }^{\circledR}$ ).

\section{Ethical aspects}

This work was approved by the Ethics Committee for Research with Human Beings (CEP) of the Federal University of Amazonas (UFAM) - CAAE/UFAM: 29406319.2.0000.5020. All the volunteers who agreed to participate in the study signed the informed consent form.

\section{Sample population}

The biological samples used in this study were obtained from 30 people from the municipality of Rio Preto da Eva $\left(2^{\circ} 41^{\prime} 55^{\prime \prime} \mathrm{S}, 59^{\circ} 42^{\prime} 3^{\prime} \mathrm{W}\right)$, Amazonas state, Brazil, who sought treatment at a basic healthcare unit (UBS), in the period from March to June 2020. The participants in this study were divided into three groups: before treatment, after treatment and negative control, according to Table 1.

All the primoinfected patients underwent a physical examination and the diagnosis for $\mathrm{CL}$ was based on the detection of Leishmania sp. amastigotes, from scarification of the inner edge of the lesion and smears stained with rapid the Panotic Kit (Laborclin ${ }^{\mathrm{TM}}$ ). Samples of the edge of the lesion of each patient were inoculated in NNN (Neal, Novy and Nicolle) culture media for parasitological confirmation of promastigote forms of the parasite.

\section{Blood sampling and PBMC extraction}

Around $8 \mathrm{~mL}$ of heparinized blood was collected from all study participants. The blood samples were transferred to 
centrifuge tubes, diluted in complete RPMI (Roswell Park Memorial Institute) medium at a 1:1 ratio and had $8 \mathrm{~mL}$ Histopaque $^{\mathrm{TM}} 1077$ carefully added. The tubes were centrifuged at 2,200 rpm for 30 minutes. The peripheral mononuclear cells (PBMCs) were collected and transferred to centrifuge tubes, washed twice with RPMI medium, and then centrifuged at $1,800 \mathrm{rpm}$ for 10 minutes at $4{ }^{\circ} \mathrm{C}$. The PBMCs were resuspended in $1 \mathrm{~mL}$ of complete RPMI medium and counted in the Neubauer chamber with the aid of Trypan blue. The concentration of PBMCs was adjusted to $2 \times 10^{5}$ cells $/ \mathrm{mL}$ in complete RPMI medium.

Table 1. Participants in the study from Rio Preto da Eva, Amazonas, Brazil organized by group and the inclusion criteria used in the research.

\begin{tabular}{c|l}
\hline Group & \multicolumn{1}{|c}{ Inclusion criteria } \\
\hline $\begin{array}{l}\text { Before treatment } \\
\text { (primoinfection) }\end{array}$ & $\begin{array}{l}\text { Untreated patients with first Leishmania } \\
\text { infection }\end{array}$ \\
\hline
\end{tabular}

Patients post Glucantime ${ }^{\circledR}$ treatment for cutaneous leishmaniasis with healed lesions.

After Blood collection of this group was performed

treatment after full healing of the lesion and clinical evaluation to ensure that the lesion was no longer active, at least 30 days and up to 12 months after treatment.

Healthy individuals, without clinical manifestations or lesions caused by Leishmania spp.

Negative control

The healthy individuals were from the metropolitan area of Manaus, and epidemiological questionnaire was applied to ensure that these individuals had not been in an endemic area in recent months.

The number of participants in each group was $n=10$.

\section{In vitro cell stimulation assays}

The PBMCs were transferred to culture microplates of flatbottomed 96-well plates; each well containing $100 \mu \mathrm{L} / \mathrm{PBMC}$ $\left[2 \times 10^{5}\right]$. The tests were individually carried out with the PBMC samples from each participant. The wells of the microplates, with $100 \mu \mathrm{L} /$ well fr each test substance (final volume of 200 $\mu \mathrm{g} / \mathrm{well})$, were organized in triplicate as follows: wells containing cells stimulated with phytohemagglutinin-PHA [10 $\mu \mathrm{g} / \mathrm{mL}]$, considered the positive control for lymphoproliferative response; wells without stimulation (with only RPMI medium) were considered the negative control; wells with cells treated with Glucantime ${ }^{\circledR}[100 \mu \mathrm{g} / \mathrm{mL}]$; and wells with cells treated with the DCM fraction $[120 \mu \mathrm{g} / \mathrm{mL}]$.

Prior to this, both substances were diluted in RPMI medium, and the DCM fraction was first dissolved in DMSOdimethylsulfoxide $\left(\mathrm{CH}_{2}\right)_{2} \mathrm{SO} \quad(1 \%)$. The PBMCs were incubated for $72 \mathrm{~h}$ at $37{ }^{\circ} \mathrm{C}\left(5 \% \mathrm{CO}_{2} ; 95 \%\right.$ humidity $)$ and, after 18 hours of incubation, BrdU (5-bromo-2'-deoxyuridine) [10 $\mu \mathrm{M} / \mathrm{mL}]$ was added. An ELISA (enzyme-linked immunosorbent assay) colorimetric test was performed according to the manufacturer's instructions (BrdU Cell Proliferation ELISA Kit, Biotrak, Amersham, UK).

Lymphoproliferation was evaluated based on the quantification of BrdU incorporation, by means of the average increase in optical density through spectrophotometry (absorbance of $450 \mathrm{~nm}$ ). Estimates of cell proliferation were determined as a relative value between the arithmetic mean of positive and negative control triplicates (white, well with RPMI medium), in relation to wells with stimulated cells.

\section{Statistical analysis}

The statistical analysis was carried out using GraphPad Prism® software v.6.0 for Windows, for which the significance $(\mathrm{p}<0.05)$ was calculated using parametric tests. A one-way ANOVA statistical test was used for comparisons among groups of study subjects and the Tukey test was used for comparisons among the drug treatments.

\section{Results and Discussion}

During the treatment, epidemiological investigations and clinical evaluations were performed on the 20 patients diagnosed with CL. Of these, ten were positive direct examination primoinfected patients, and ten were patients who had achieved clinical cure, which was evaluated according to wound healing, after treatment with Glucantime ${ }^{\circledR}$. There was a predominance of CL in males (85\%), and $76.47 \%$ were in the age group between 19 and 56 years. The higher prevalence of males, who are young and are involved in forest extractivism are part of the epidemiological profile of ATL in the Brazilian Amazon (Figueira et al., 2017; Hernández \& Núñes, 2019).

Regarding the CL lesions, $91.30 \%$ were ulcerated lesions, with a mean size of $2.0 \mathrm{~cm}, 62.86 \%$ of which were located in the lower limbs and $13.04 \%$ in the upper limbs and trunk (Figure 1). Figueira et al. (2017) also described a higher prevalence of ulcerated lesions of the CL, as well as a high frequency of lesions in the lower limbs. However, the study by Hernández \& Núñes (2019), also conducted with patients living in the municipality of Rio Preto da Eva, in the period from 2014 to 2016, found a lower number of lesions in the lower limbs. In contrast, Sampaio et al. (2009) and Hernández and Núñes (2019) noted a higher frequency of patients with CL lesions in the upper limbs, in the municipalities of Rio Preto da Eva and Tefé in the Amazonas state, and in Brasília, DF.

Of the 30 subjects involved in this study, mononuclear cells from 21 participants ( 7 samples/group) were analyzed in vitro. The lymphoproliferative response was expressed in high rates $(\geq 60 \%)$ (Figure 2 ) of PBMCs in the primoinfected $(\mathrm{p}=0.0873)$ (Figure 2A), post-treatment $(\mathrm{p}=0.0135)$ (Figure $2 \mathrm{~B})$ and negative control $(\mathrm{p}=0.0624)$ (Figure $2 \mathrm{C}$ ) groups with the stimulus by the DCM fraction, conventional treatment with Glucantime ${ }^{\circledR}$ and PHA mitogen.

The lymphoproliferation of PBMC was strongly positive $(100 \%)$ and significant in response to PHA mitogen (Figure 2) and was verified in all groups of participants. PHA mitogen is commonly used as a lymphoproliferation enhancer and has been used in other studies (Reis et al., 2009; Mohammadi, Duthie, Reed, Javadi, \& Khamesipour, 2021). 


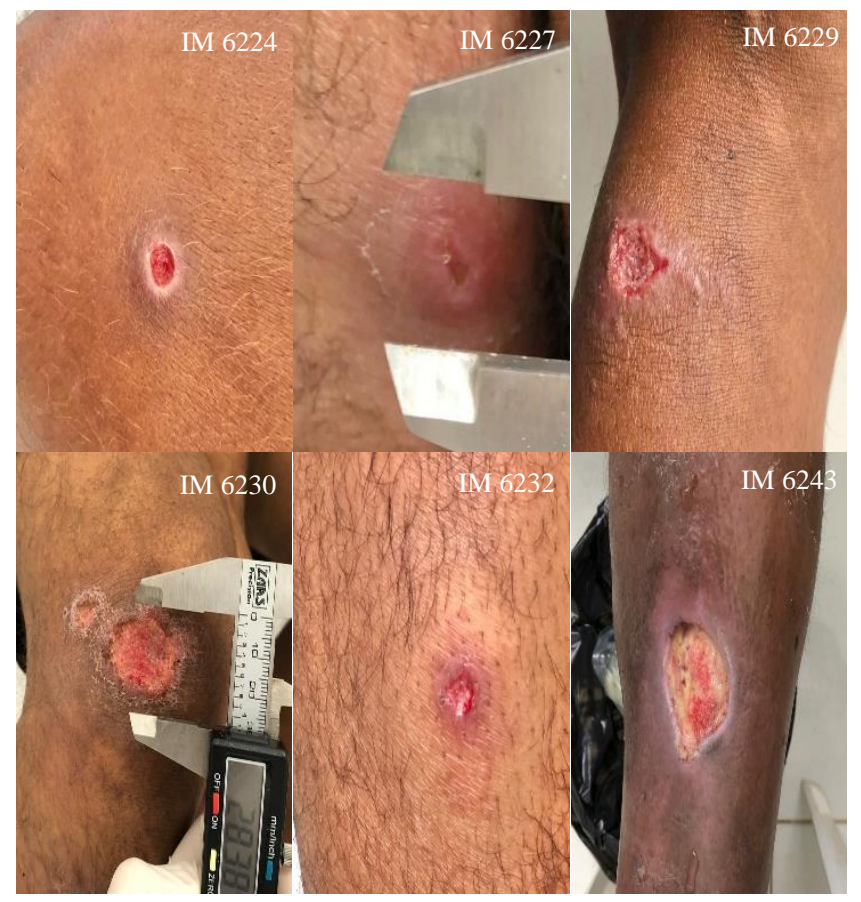

Figure 1. Clinical aspects of lesions in male patients primoinfected with cutaneous leishmaniasis (CL) treated in Rio Preto da Eva, Amazonas, Brazil, during March to May 2020. IM: Registration code.

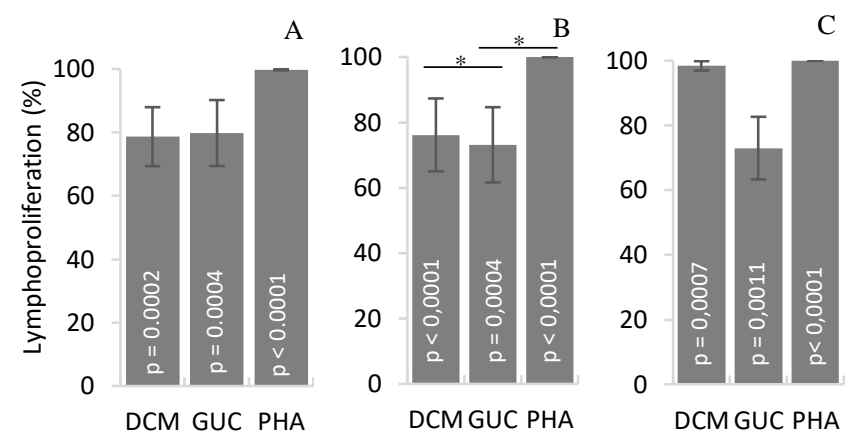

Figure 2. PBMC lymphoproliferation of participants evaluated in Rio Preto da Eva, Amazonas state, Brazil, during March and May 2020. A - primoinfected patients with cutaneous leishmaniasis; B - post-treatment cutaneous leishmaniasis patients; C - healthy people without cutaneous leishmaniasis. DCM: dichloromethane fraction; PHA: phytohemagglutinin. Vertical lines represent standard error. *Horizontal lines represent statistical significance between treatments $(\mathrm{p}<0.005)$.

The PBMC cultures from all the groups showed a significant lymphoproliferative response $(\geq 77 \% ; p<0.0007)$ to the dichloromethane fraction (DCM) (Figure 2). In particular, the group of post-treatment patients, in particular, presented almost $100 \%$ proliferated cells induced by DCM. Thus, the DCM fraction induced more cell proliferation than Glucantime $^{\circledR}$, which was different to that observed for the primoinfected and negative control groups, since the values between the substances were equivalent.

This result of expressive lymphoproliferation may be related to the therapeutic biological potential of the fraction of L. ferrea obtained, whose antileishmanial activity was confirmed against $L$. (L.) amazonensis and L. (V.) guyanensis and did not present cytotoxic effects in murine macrophages (Comandolli-Wyrepkowski et al., 2017). To date, the mechanism of action of the pharmacological components of L. ferrea in vivo is not yet known. However, promising effects of $L$. ferrea for the treatment of CL were observed by Comandolli-Wyrepkowski et al. (2017), when submitting Golden hamsters (Mesocricetus auratus) that were infected with $L$. (L.) amazonensis and $L$. (V.) guyanensis to topical treatment with a hydrogel containing the DCM fraction of $L$. ferrea. Control of the growth of the CL lesions in animals and low parasitic load in culture analyses were noted after treatment.

The phytochemical prospecting of the extract of L. ferrea showed the presence of phenolic compounds and flavonoids in greater evidence (Comandolli-Wyrepkowski et al., 2017). Phenolic compounds are recognized as being involved in anti-inflammatory and antioxidant activity, and act directly on specialized cells of the immune system (Hakime-Silva et al., 2013). Vila-Nova et al. (2012) demonstrated leishmanicidal activity of the phenolic compound coumarin (scoporone) isolated from Platymiscium floribundum, and of the flavonoids (rutin and quercetin) that were isolated from Dimorphandra gardneriana. These are both plants that are native to the Caatinga biome of Brazil, and in this case were against Leishmania infantum, which are the protozoa that cause visceral leishmaniasis. These compounds were able to inhibit the enzyme acetyl-cholinesterase (AChE) and, consequently, disrupt the biosynthesis of phosphatidylcholine, an essential constituent of the surface membranes of the parasite.

Among some of the important phenolic compounds found in L. ferrea is gallic acid. Associating these phenolic compounds and amphotericin B, Alves (2019) demonstrated the activation of macrophages and a reduction in amastigotes through macrophage, indicating therapeutic action and activation of the immune response, and leading to the healing of lesions in Mus musculus lineage BALB/c. Some studies with herbal compounds, such as Campsiandra laurifolia (Chagas, Henrique Müller, Soares \& Garcez, 2010), Portulaca hirsutissima and Portulaca werdermannii (Costa et al., 2007), Nelumbo nucifera (Khan et al., 2016), did not demonstrate direct action on the parasitic agent, but rather, as potential anti-inflammatory treatments with high immunomodulatory capacity in Leishmania sp. infections.

Considering the PBMCs exposed to Glucantime ${ }^{\circledR}$, all the groups had a high rate of lymphoproliferation in response to Glucantime $^{\circledR}(\leq 70 \% ; p<0.001)$ (Figure 2$)$. The treatment of CL with antimonials promotes changes in the immune response of the host, corroborating with the modulation of the immune system, increased the ability of direct destruction or gradual elimination of the parasite (Brelaz-deCastro et al., 2012). The rate of cell proliferation of the samples of PBMC exposed to Glucantime ${ }^{\circledR}$ from posttreatment subjects $(73 \%)$ (Figure 2B) was reasonably lower than that of the samples of the primoinfected $(79 \%)$ patients (Figure 2A). These data corroborate the findings of Toledo et al. (2001), who also observed a decrease in lymphoproliferative response after treatment, in PBMC 
stimulated with total antigen of $L$. (V.) braziliensis. The authors pointed out that in an in vivo study, $\mathrm{T}$ cell stimulation is expected to decrease as treatment progresses to cure, since the reduction in parasitic load can cause the number of responsive $\mathrm{T}$ cells to decrease. It is worth remembering that in both studies, blood collection of post-treatment patients was performed at least 30 days after the end of Glucantime ${ }^{\circledR}$ treatment.

The toxicity of meglumine antimoniate goes far beyond the adverse effects on the vital organs of CL patients while being treated. Lopez (2015) observed that antimoniate interfered in the process of cell proliferation, in addition to contributing cytotoxic, genotoxic and mutagenic effects in human leukocytes exposed to different concentrations of Glucantime ${ }^{\circledR}$. Given this, the combination therapy of potential drugs and antimoniate have numerous advantages, such as reduced toxicity, ease in the treatment regimen and reduced development of resistance to this drug.

Lymphoproliferation is considered an important factor in the control of infection or even in the elimination of Leishmania sp. (Brasil, 2017). Therefore, the discovery of phytopharmaceuticals with immunomodulatory capabilities are crucial for the development of alternative treatments or for combination with recommended drugs, in order to provide a potential synergism and therapeutic success in treating leishmaniasis. This study contributes to a more diligent look at the importance of the immunomodulatory effect of $L$. ferrea that may favor the healing of lesions in patients with CL. However, for the best elucidation of the regulation of inflammation induced by the DCM fraction, it is necessary to perform cytokine dosage to understand these immune mechanisms.

\section{Conclusion}

These findings suggest that the organic fraction DCM induced stimulatory action on activation and lymphoproliferation when incubated with the PBMC of patients before and after treatment for CL, which may, at least in part, be due to an immunomodulatory response. This immunomodulatory response needs to be highlighted and better investigated in future trials in order to strengthen the data presented here in order to demonstrate which molecular mechanisms are involved and the stimulatory effect of the immune response caused by the dichloromethane fraction of $L$. ferrea, a phytopharmaceutical candidate for the alternative treatment of cutaneous leishmaniasis.

\section{Acknowledgments}

The authors would like to thank the Amazonas State Research Support Foundation - FAPEAM (POSGRAD) for its financial support, and the Edible Fungi Cultivation Laboratory for its collaboration with the spectrophotometry experiments.

\section{References}

Alves, M. M. M. (2019). Anfotericina B convencional associada ao ácido gálico e ao ácido elágico em formulação tópica para terapia antileishmania (Doctoral thesis). Universidade Federal do Piauí, Centro de Ciências Agrárias, Pós-graduação em Ciência Animal. Biblioteca Setorial do Centro de Ciências Agrárias.
Bacellar, O., Lessa, H., Schriefer, A., Machado, P., Ribeiro de Jesus, A., Dutra, W. O., Gollob, K. J., \& Carvalho, E. M. (2002). Up-regulation of Th1-type responses in mucosal leishmaniasis patients. Infection and Immunity, 70(12), 6734-6740. doi: 10.1128/IAI.70.12.6734-6740.2002

Brasil. Ministério da Saúde. (2006). A fitoterapia no SUS e o Programa de Pesquisa de Plantas Medicinais da Central de Medicamentos. Secretaria de Ciência, Tecnologia e Insumos Estratégicos. Departamento de Assistência Farmacêutica. 1. ed. Brasília: Editora Ideal Ltda.

Brasil. Ministério da Saúde. (2017). Manual de vigilância da leishmaniose tegumentar [recurso eletrônico] / Ministério da Saúde, Secretaria de Vigilância em Saúde, Departamento de Vigilância das Doenças Transmissíveis.

Brelaz-de-Castro, M. C., Almeida, A. F., Oliveira, A. P., Assis-Souza, M., Rocha, L. F., \& Pereira, V. R. (2012). Cellular immune response evaluation of cutaneous leishmaniasis patients cells stimulated with Leishmania (Viannia) braziliensis antigenic fractions before and after clinical cure. Cellular Immunology, 279(2), 180-186. doi: 10.1016/j.cellimm.2012.11.006

Carvalho, F. G., Sampaio, J. P. S., Araújo, M. M. S, Pinto, L. S. S., \& Rocha, A. J. (2016). Assessment of the healing activity of jucá pods [Libidibia ferrea (Mart. ex Tul.) L. P. Queiroz] in cutaneous lesions of rats. Acta Scientiarum. Technology, 38(2), 137-143.

Carvalho, S. H., Frézard, F., Pereira, N. P., Moura, A. S., Ramos, L. M. Q. C., Carvalho, G. B., \& Rocha, M. O. C. (2019). American tegumentary leishmaniasis in Brazil: a critical review of the current therapeutic approach with systemic meglumine antimoniate and short-term possibilities for an alternative treatment. Tropical Medicine \& International Health, 24(4), 380-391. doi: 10.1111/tmi. 13210

Chagas, A. P., Henrique Müller, A., Soares, M., \& Garcez, L. M. (2010). Potencial anti-Leishmania e imunomodulador dos extratos de Campsiandra laurifolia Benth. (Fabaceae). Revista Pan-Amazônica de Saúde, 1(1), 117-124. doi: 10.5123/S2176-62232010000100017

Comandolli-Wyrepkowski, C. D., Jensen, B. B., Grafova, I., Santos, P. A., Barros, A. M. C., Soares, F. V., Barcellos, J. F. M., Silva, A. F., Grafov, A., \& Franco, A. M. R. (2017). Atividade antileishmania de extratos de Libidibia ferrea: desenvolvimento de testes in vitro e in vivo. Acta Amazonica, 47(4), 331-340. doi: 10.1590/1809-4392201700871

Costa, J. F., Kiperstok, A. C., David, J. P., David, J. M., Giulietti, A. M., Queiroz, L. P., Santos, R. R., \& Soares, M. B. (2007). Anti-leishmanial and immunomodulatory activities of extracts from Portulaca hirsutissima and Portulaca werdermannii. Fitoterapia, 78(7-8), 510514. doi: 10.1016/j.fitote.2007.05.005

Espir, T. T., Figueira, L. P., Naiff, M. F., Costa, A. G., Ramalho-Ortigão, M., Malheiro, A., \& Franco, A. M. R. (2014). The Role of Inflammatory, Anti-Inflammatory, and Regulatory Cytokines in Patients Infected with Cutaneous Leishmaniasis in Amazonas State, Brazil. Journal of Immunology Research. doi: 10.1155/2014/481750

Falcão, T. R., Araújo, A. A., Soares, L. A. L., Farias, I. B., Silva, W. A. V., Ferreira, M. R. A., Araújo, R. F. Jr., Medeiros, J. S., Lopes, M. L. D. S., \& Guerra, G. C. B. (2019). Libidibia ferrea Fruit Crude Extract and Fractions Show Anti-Inflammatory, Antioxidant, and Antinociceptive Effect In Vivo and Increase Cell Viability In Vitro. Evidence-based Complementary and Alternative Medicine, 6064805. doi: $10.1155 / 2019 / 6064805$

Figueira, L. P., Soares, F. V., Júnior, R. D. N., Vinhote-Silva, A. C., Silva, S. S., Espir, T. T., Naiff, M. F., Gomes, L. H. M., Moreira, F. R. A. C. N., \& Franco, A. M. R. (2017). New human case reports of cutaneous leishmaniasis by Leishmania (Viannia) naiffi in the Amazon region, Brazil. Acta Amazonica, 47(1), 47-52. doi: 10.1590/18094392201601484

Hakime-Silva, R. A., Vellosa, J. C. R., Khalil, N. M., Khalil, O. A. K., Brunetti, I. L., \& Oliveira, O. M. M. F. (2013). Chemical, enzymatic and cellular antioxidant activity studies of Agaricus blazei Murrill. Anais da Academia Brasileira de Ciências, 85(3), 1073-1082. doi: 10.1590/S0001-37652013005000044

Hernández, C. M. C., \& Núñez, V. P. (2019). Caracterización clínicoepidemiológica de la leishmaniasis cutánea. UBS Manápolis, Rio Preto da Eva, Amazonas, Brasil. Dermatología Cosmética, Médica y Quirúrgica, 17(1): 8-12.

Khan, S., Khan, H., Ali, F., Khan, N. M., Shah, A., \& Rahman, S. U. (2016). GC-MS Analysis of Fixed Oil from Nelumbo nucifera Gaertn Seeds: Evaluation of Antimicrobial, Antileishmanial and Urease Inhibitory Activities. Journal of the Chemical Society of Pakistan, 38(06), 11681173. 
Lopez, G. T. (2015). Efeitos do Antimoniato de N-Metilglucamina e SBV sobre parâmetros citotóxicos, genotóxicos e mutagênicos em cultura de leucócitos humanos (Master's dissertation). Universidade Federal do Pampa, Pós-Graduação em Ciências Farmacêuticas. Biblioteca do Sistema GURI (Gestão Unificada de Recursos Institucionais).

Mohammadi, A. M., Duthie, M. S., Reed, S. G., Javadi, A., \& Khamesipour, A. (2021). Evolution of antigen-specific immune responses in cutaneous leishmaniasis patients. Parasite Immunology, 43(4), e12814. doi: 10.1111/pim. 12814

Reis, L. C., Brito, M. E., Souza, M. A., Medeiros, A. C., Silva, C. J., Luna, C. F., \& Pereira, V. R. (2009). Cellular immune response profile in patients with American tegumentary leishmaniasis prior and post chemotherapy treatment. Journal of Clinical Laboratory Analysis, 23(1), 63-69. doi: 10.1002/jcla.20291

Sampaio, R. N. R., Gonçalves, M. C., Leite, V. A., França, B. V., Santos, G., Carvalho, M. S. L., \& Tauil, P. L. (2009). Estudo da transmissão da leishmaniose tegumentar americana no Distrito Federal. Revista da Sociedade Brasileira de Medicina Tropical, 42(6), 686-690. doi: 10.1590/S0037-86822009000600015

Sinan. Sistema de Informação de Agravos de Notificação. Leishmaniose Tegumentar Americana. Ministério da Saúde.

Pradhan, S., Schwartz, R. A., Patil, A., Grabbe, S., Goldust, M. Comprehensive Review on Treatment Options of Leishmaniasis. Clin Exp Dermatol. 2021. doi: 10.1111/ced.14919

Teixeira, M. J., Teixeira, C. R., Andrade, B. B., Barral-Netto, M., \& Barral, A. (2006). Chemokines in host-parasite interactions in leishmaniasis. Trends in Parasitology, 22(1): 32-40. doi: 10.1016/j.pt.2005.11.010

Toledo, V. P. C. P., Mayrink, W., Gollob, K. J., Oliveira, M. A. P., Costa, C. A., Genaro, O., Pinto, J. A., \& Afonso, L. C. C. (2001). Imunoquimioterapia na leishmaniose tegumentar americana: aspectos imunológicos antes e após o tratamento. Memórias do Instituto Oswaldo Cruz, 96(1), 89-98. doi: 10.1590/S0074-02762001000100010

Vila-Nova, N. S., Morais, S. M., Falcão, M. J. C., Bevilaqua, C. M. L., Rondon, F. C. M., Wilson, M. E., Vieira, I. G. P., \& Andrade, H. F. (2012). Leishmanicidal and cholinesterase inhibiting activities of phenolic compounds of Dimorphandra gardneriana and Platymiscium floribundum, native plants from Caatinga biome.Pesquisa Veterinária Brasileira, 32(11), 1164-1168. doi: 10.1590/S0100736X2012001100015

License: Creative Commons CC BY NC 4.0 